\title{
Tolerance to water deficit in young trees of jackfruit and sugar apple ${ }^{1}$
}

\author{
Tolerância ao déficit hídrico em plantas jovens de jaqueira e pinheira
}

\author{
Bruno Monteiro Rodrigues², Bruna Dias Souza ${ }^{3}$, Rejane Mansur Nogueira ${ }^{4}$ e Mauro Guida Santos ${ }^{5 *}$
}

\begin{abstract}
The predawn leaf water potential $\left(\Psi_{1}\right)$, stomatal conductance $\left(g_{s}\right), \mathrm{CO}_{2}$ assimilation $(A)$, transpiration $(E)$, chlorophyll $a$ fluorescence and leaf metabolite contents (soluble sugars, proteins and free amino acids) of two tropical fruit species grown in a greenhouse were evaluated to determine the effect of induced water stress on young plants. Six month-old jackfruit (Artocarpus heterophyllus Lam.) and sugar apple (Annona squamosa L.) plants were evaluated in $10.0 \mathrm{~L}$ pots after eight days of water withholding, imposed by suspension of irrigation. Jackfruit water status was better than sugar apple. Sugar apple plants showed different daily stomatal behavior when well hydrated, compared to jackfruit plants under the same conditions. The gas exchange of both species showed sensibility to high vapor pressure deficit (VPD). However, under water deficit, photochemical efficiency dropped at midday in both treatments (control and water deficit) and both species showed low tolerance to high VPD and light intensity under greenhouse conditions. In contrast, some chlorophyll fluorescence variables showed good photosystem II stability at highest VPD hour (14:00 h). The present results involving carbohydrate metabolic changes revealed an accumulation of soluble sugars; moreover, protein and free amino acid contents in water stressed leaves also increased. These findings suggest an absence of damage to photosynthetic machinery for water deficit period. Jackfruit revealed greater tolerance to water deficit than sugar apple an important feature for commercial crops in northeastern Brazil.
\end{abstract}

Key words - Annona squamosa. Artocarpus heterophyllus. Semi-arid. Tropical fruit. Water relations.

\begin{abstract}
Resumo - A condutância estomática $\left(g_{s}\right)$, a assimilação de $\mathrm{CO}_{2}(A)$, a transpiração $(E)$, a fluorescência da clorofila e o conteúdo foliar de (açúcares solúveis, proteínas e aminoácidos livres) de duas espécies frutíferas tropicais foram avaliados para determinar o efeito do déficit hídrico induzido sobre as plantas da jaqueira (Artocarpus heterophyllus Lam.) e da pinheira (Annona squamosa L.) de seis meses de idade foram cultivadas em potes com capacidade para 10,0 L e foram avaliadas após oito dias de suspensão da irrigação. A jaqueira quando bem hidratada, foi melhor do que a pinheira. Plantas de pinheira apresentaram comportamento diferente quanto à condutância estomática diária quando comparada com as plantas de jaqueira, ambas bem hidratadas. As trocas gasosas de ambas as espécies apresentaram alta sensibilidade ao déficit pressão de vapor (DPV). No entanto, sob déficit hídrico, a eficiência fotoquímica decresceu ao meio-dia em ambos os tratamentos (controle e déficit hídrico) e ambas as espécies apresentaram baixa tolerância ao alto DPV e intensidade da luz em casa de vegetação. Em contrapartida, algumas variáveis de fluorescência de clorofila mostraram boa estabilidade na hora de maior DPV (14:00 h), indicando estabilidade do fotossistema II. Os resultados envolvendo alterações metabólicas revelaram um acúmulo de açúcares solúveis, além disso, o conteúdo foliar de proteínas e aminoácidos livres em plantas bem hidratadas também aumentou. Estes resultados sugerem uma ausência de danos ao maquinário fotossintético durante ao período de déficit hídrico. A jaqueira revelou uma maior tolerância ao período de déficit hídrico do que a pinheira.
\end{abstract}

Palavras-chave - Annona squamosa. Artocarpus heterophyllus. Frutas tropicais. Relações hídricas. Semi-árido.

\footnotetext{
* Corresponding author

${ }^{1}$ Received 12/06/2009; accepted 10/03/2010

Parte da Monografia do primeiro autor apresentada ao curso de Bacharelado de Ciências Biológicas/UFPE

${ }^{2}$ Departamento de Botânica, UFPE, Recife-PE, Brasil, bruno.rafael@gmail.com

${ }^{3}$ Departamento de Botânica, UFPE, Recife-PE, Brasil, brunadssouza@yahoo.com.br

${ }^{4}$ Departamento de Biologia, UFRPE, Recife-PE, Brasil, rjmansur1@gmail.com

${ }_{5}^{5}$ Departamento de Botânica, UFPE, Recife-PE, Brasil, mauroguida@yahoo.com.br
} 


\section{Introduction}

Low water availability is the most serious environmental constraint on agricultural production. Thus, more efficient use of water resources may be a solution for increased plant productivity in water-deficit environments (SINCLAIR et al., 2008), especially in semiarid areas (CHAVES et al., 2003), like northeastern Brazil (ENDRES, 2007).

It is well known that the rate of $\mathrm{CO}_{2}$ assimilation in leaves is depressed at moderate leaf water deficits or even before leaf water status alters in response to a drop in air humidity (KRAMER; BOYER, 1995) or in soil water potential (CHAVES et al., 2003; LAWLOR, 2002; SANTOS et al., 2006). Stomatal limitation is considered to decrease both $\mathrm{CO}_{2}$ assimilation and $\mathrm{CO}_{2}$ concentration in the intercellular spaces of the leaf, which inhibits leaf metabolism (LAWLOR, 2002; SANTOS et al., 2006). Nonethelesss, the limitations to $\mathrm{CO}_{2}$ assimilation imposed by stomatal closure may promote an imbalance between photochemical activity at photosystem II (PSII) and electron requirement for photosynthesis, leading to an overexcitation and subsequent photoinhibitory damage of PSII reaction centers (SANTOS et al., 2006). Chlorophyll fluorescence can be a very sensitive probe of the physiological status of leaves, which can provide very rapid assessment of plant performance in a wide range of situations (MAXWELL; JOHNSON, 2000).

Under such environmental stress, it is clear that numerous fruit species show altered carbohydrate content in shoot tissues (SIRCELJ et al., 2007; SIVACI, 2006). Carbohydrates are the main source of energy for the metabolic changes that occur during certain environmental stresses (SIVACI, 2006), though the accumulation of free amino acids is also common (SIRCELJ et al., 2007). Moreover, soluble sugar and amino acid contents act contrary to one another, as reported by Wingler et al. (2006) for senescence, a factor induced by drought (HSIAO, 1973), and can be viewed as metabolic signals for physiological responses to drought (ROLLAND et al., 2006; SANTOS; PIMENTEL, 2009; SIRCELJ et al., 2007).

Only a few tropical tree crops of economic importance have received a certain level of basic research regarding environmental physiology (DAMATTA, 2007). Several gaps exist in the database concerning the ecophysiology of tropical tree crops (MIRANDA et al., 2008; OKUMURA et al., 2008), mainly when considering environmental factors, such as water availability and temperature (DAMATTA, 2007).

Sugar apple (Annona squamosa L.) currently occupies an area around 10,000 ha in Brazil and, in general presents very low productivity in northeastern
Brazil (around 3 tons $\mathrm{ha}^{-1}$ ). However, in some areas of the northeast, where sugar apple is grown using assistive technology, such as irrigation, yields may reach 25 tons ha-1 (ALBUQUERQUE, 1997). Jackfruit (Artocarpus heterophyllus Lam.) is cultivated in all tropical countries worldwide and is generally consumed in natura. This tree is grown without any assistive technology, but it has great potential because of the numerous possibilities for its use after harvesting. No records exist regarding its productivity in northeastern Brazil.

The main goal of this work was to characterize water relations and some components of carbon metabolism in nursery trees of two tropical fruit species: Sugar apple (Annona squamosa L.) and Jackfruit (Artocarpus heterophyllus Lam.).

\section{Material and methods}

\section{Plant material and growth conditions}

The study was conducted on two tropical fruit species: sugar apple (Annona squamosa L.); and jackfruit (Artocarpus heterophyllus Lam.). The young plants (six months-old) were obtained by grafting method and kept in a greenhouse conditions. The research was carried out between September and October, 2007 in Recife the State of Pernambuco, Northeastern Brazil.

\section{Treatments conditions}

The nursery trees were planted in $10.0 \mathrm{~L}$ pots (one plant per pot), containing $8.0 \mathrm{~kg}$ of soil (horizon 0 to $30 \mathrm{~cm}$ of a red yellow podzolic soil) and washed sand mixture $(3: 1)$. The plants were fertilized every 30 days with $500 \mathrm{~mL}$ of a modified Hoagland solution (SANTOS et al., 2006). What kept them without any sign of nutritional deficiency. The air temperature change between 18 and $32{ }^{\circ} \mathrm{C}$, and air humidity change 48 to $91 \%$ during the cycle of the plants. The pots were irrigated daily until the onset of drought treatment imposed, by suspension of irrigation on half the plants, 120 days after acclimatization. After eight days of drought the plants were irrigated again.

\section{Leaf water status}

The xylem water tension was measured after eight days without irrigation with a Scholander pressure chamber (Soilmoisture Equipment Corp., Santa Barbara, CA, USA) in a fully expanded leaf from the middle shoot of the plant, a mature but not senescent leaf. These measurements were assumed to measure the leaf water potential $\left(\Psi_{1}\right)$ and were performed at two time points, predawn and 14:00 $\mathrm{h}$ (maximum VPD hour). 


\section{Stomatal conductance, transpiration and net $\mathrm{CO}_{2}$ assimilation rate}

The gas exchange measurements were performed during day 8 of induced drought at two moments: from 08:00 to $09: 00 \mathrm{~h}$ and $13: 30$ to $14: 30 \mathrm{~h}$, to determine low and high VPD under sunlight. For this, a Portable Infrared $\mathrm{CO}_{2}$ Gas Analyzer (IRGA), ADC, model Lci (Hoddesdon, UK) was used. Measurement at 08:00 $\mathrm{h}$ avoided the high VPD (around $2.1 \mathrm{kPa}$ ), which was present at 14:00 h (around $3.6 \mathrm{kPa}$ ). The net $\mathrm{CO}_{2}$ assimilation rate $(A), g_{s}$ and $E$ were analyzed. Leaf gas exchange was measured in a mature but not senescent leaf, in the middle of plant with $1080 \mu \mathrm{mol} \mathrm{m} \mathrm{m}^{-2} \mathrm{~s}^{-1}$ of PAR (photosynthetic active radiation), maximum radiation in leaf cuvette of IRGA. The local PAR at the time of measurement was $1500 \mu \mathrm{mol} \mathrm{m} \mathrm{m}^{-2} \mathrm{~s}^{-1}$ and the mean temperature at 08:00 $\mathrm{h}$ was $27.1^{\circ} \mathrm{C}$ and at $14: 00 \mathrm{~h}$ was $35.8^{\circ} \mathrm{C}$.

\section{Chlorophyll fluorescence}

Chlorophyll $a$ fluorescence was measured (only in the second experiment) with an ADC fluorometer (Hoddesdon, UK), wherein the maximal $\left(F_{m}\right)$ and minimum $\left(F_{o}\right)$ fluorescence yields were obtained in darkadapted (30 $\mathrm{min})$ leaves and steady-state $\left(F_{s}\right)$ and maximal $\left(F_{m}{ }^{\prime}\right)$ fluorescence yields were measured in light-adapted leaves (VAN KOOTEN; SNEL, 1990).

\section{Leaf soluble sugar, protein, free amino acid and chlorophyll contents}

Leaf samples were collected at midday (13:00 to 14:00 h), immediately frozen in liquid nitrogen and stored at $-20^{\circ} \mathrm{C}$ in humidity proof containers until analysis.

Soluble carbohydrates were determined according to Dubois et al. (1956), using d(+)-glucose as standard. For free amino acid determination, $0.5 \mathrm{~mL}$ of $10 \%$ trichloroacetic acid was added to an aliquot of $0.5 \mathrm{~mL}$ of the water extract and the mixture was maintained at $25^{\circ} \mathrm{C}$ for one hour. This mixture was then centrifuged at $12,000 \times g$ for $5 \mathrm{~min}$ and the supernatant was used for amino acid determination (YEMM; COCKING, 1955), using l-leucine as standard.
The protein content was determined according to Bradford (1976). Chlorophyll content was determined according to Lichtenthaler and Wellburn (1983).

\section{Experimental design and statistical analysis}

The experimental design was completely randomized with two species, two water levels and four replicates. The data were subjected to analysis of variance (ANOVA) and means were compared and segregated by the Student-Newman-Keuls test $(p<0.05)$, when significance was detected (program MSTATC).

\section{Results and discussion}

The leaf water potential $\left(\Psi_{l}\right)$ was lower in sugar apple than jackfruit at both measurement points after eight days of drought (Table 1). Sugar apple plants showed low $\Psi_{l}$, at 05:00 h (predawn) in well hydrated plants and the stressed sugar apple plants presented a $\Psi_{l}$ half that of stressed jackfruit plants. Differences in $\Psi_{l}$ behavior between species or cultivars under drought could thus be related to the water-conducting capacity and stomatal behavior in response to a hydraulic signal (SCHULTZ, 2003; SINCLAIR et al., 2008).

Prior to the water deficit period, the plants showed high values of stomatal conductance $\left(g_{s}\right)$ and transpiration $(E)$, during the day. The behavior of each species was different, jackfruit showed similar isohydric behavior, while sugar apple was anisohydric (Figure 1), however more evidences are necessary to conclude their behavior. When well hydrated, the plants showed distinct $g_{s}$ behaviors during the day, jackfruit started high, but by mid-morning it reached a plateau from 08:00 to 15:00 h. On the other hand, sugar apple plants presented increasing $g_{s}$ values during the morning period until 13:00 h, after this times the $g_{s}$ values decreased quickly (Figure 1). The first behavior, isohydric, also observed in maize plants by Tardieu and Simonneau (1998), does not depend on soil water status. In fact, jackfruit $g_{s}$ behavior may lead to higher water efficiency

Table 1 - Leaf water potential $\left(\Psi_{1}\right)(\mathrm{MPa})$ of two species fruit measurement at pre-dawn and 14:00 h in young plants well hydrated (control) and drought (stress). Grown in pots under greenhouse conditions in Recife $2007^{(1)}$

\begin{tabular}{ccccccc}
\hline \multirow{2}{*}{ Time } & \multicolumn{3}{c}{ Jackfruit } & & \multicolumn{2}{c}{ Sugar apple } \\
\cline { 2 - 3 } \cline { 5 - 6 } & Control & Stress & & Control & Stress \\
\hline Pre-dawn & $-0.50 \mathrm{Bc}$ & $-0.60 \mathrm{Bb}$ & & $-1.17 \mathrm{Ac}$ & $-1.30 \mathrm{Ab}$ \\
$14: 00$ & $-0.35 \mathrm{Cc}$ & $-0.83 \mathrm{BCb}$ & & $-1.27 \mathrm{ABbc}$ & $-1.63 \mathrm{Aa}$ \\
\hline
\end{tabular}

${ }^{(1)}$ Data represent the mean of three replications; different small letters in column and capital letters in line show significant difference by StudentNewman-Keuls test $(p<0.05)$ for each specie. CV 19.75\% 
use. In addition, $g_{s}$ behavior is altered in some species when they are submitted to nonnatural soils conditions. Endres (2007) observed different stomatal behavior in sugar apple under field conditions, in daily $g_{s}$ variations and $E$ curves presented alterations in shape over the year. The author reported that seasonal variation in $E$ and $g_{s}$ in irrigated sugar apples could be related to leaf age and VPD. In addition, the stomatal behavior may be related to factors such as light and temperature (CHAVES et al., 2003), thus, changing water use efficiency of the specie.

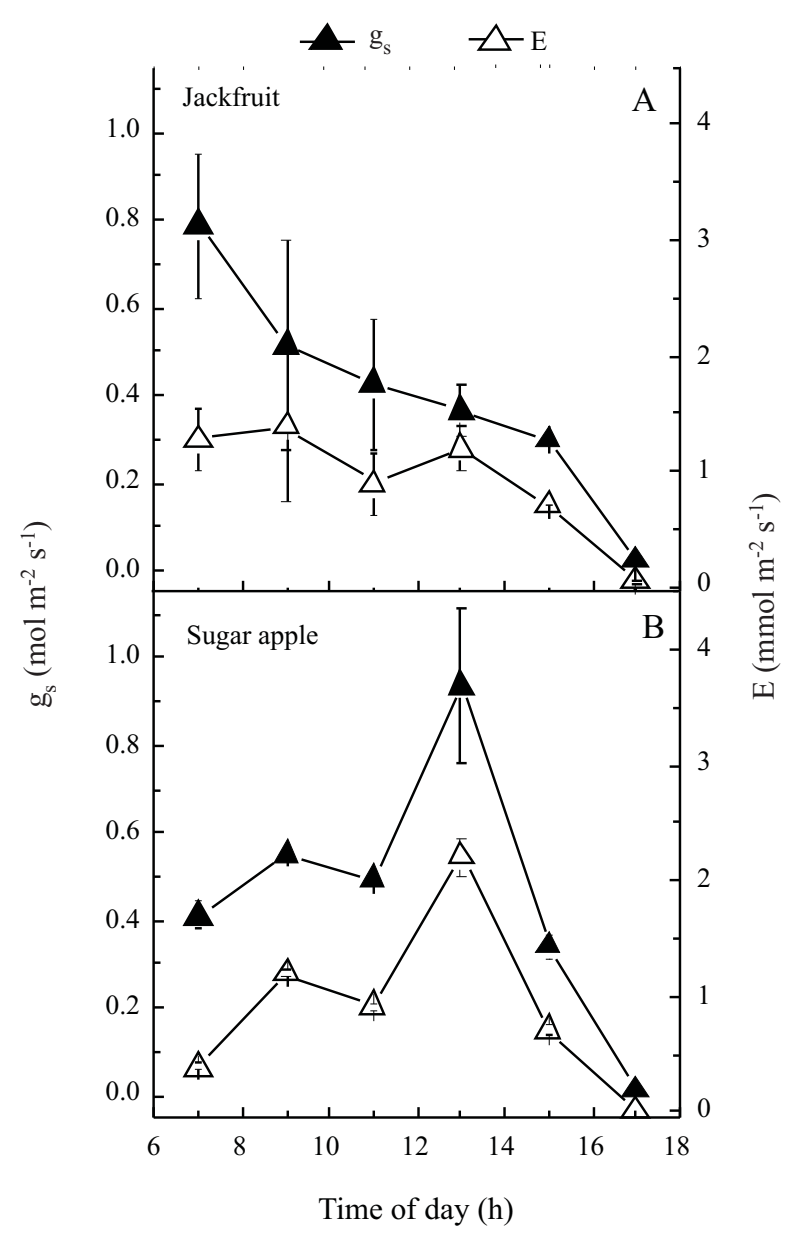

Figure 1 - Diurnal change in stomatal conductance $\left(g_{s}\right)$ and transpiration rates $(E)$ amounts from sunrise to sunset, in well watered plants of young plants of two species fruit jackfruit (A) and sugar apple (B). Cultivated in pots under greenhouse conditions, in Recife, 2007). Values are means \pm SE $(n=4)$

Jackfruit showed higher $(\mathrm{p}<0.05) g_{s}$ and $A$ values at the lowest VPD hour $(08: 00 \mathrm{~h})$ than sugar apple (Figure 2A-B, D-E). However, at the highest VPD hour
(14:00 h), both species showed low $g_{s}$ and $A$ values, with no significant difference in these values $(\mathrm{p}>0.05)$ (Figure 2A-B, D-E). Both species did not show any difference $(\mathrm{p}>0.05)$ in $E$ rate at the two points of measurements (Figure 2C,F); however, sugar apple showed a high $E$ rate compared to its $g_{s}$ and $A$ rates (Figure 2D-F). No difference was observed between control and stress treatments for all variables measured at the lowest VPD hour (08:00 h) in both species (Figure 3A-F). In contrast, at the highest VPD hour $(14: 00 \mathrm{~h})$ the control gas exchange rate decreased less than the stress rate in jackfruit (Figure 2A-F), revealing better intrinsic water use efficiency (data not shown). Water scarcity is a major constraint on increasing crop yields, particularly in many developing countries (SINCLAIR et al., 2008), including northeastern Brazil. For sugar apple, despite the plants being well hydrated (by irrigation), the VPD had a strong influence on stomatal closure during the months of drought, which did not result in a reduction in transpiration (ENDRES, 2007). Under this situation, plants presenting high water use efficiency under highVPD may be an important economic resource for the local population. On the other hand, jackfruit showed behavior that is consistent with the need for increased efficiency in resource use, i.e. water, in an effort to develop semiarid regions. Moreover, Cao et al. (2006) reported low variation in $A$ of jackfruit under natural conditions in a tropical area in China between summer and winter.

The photochemical apparatus of both species showed relative tolerance to water stress, the potential quantum efficiency of PSII $\left(F_{v} / F_{m}\right)$, in the morning, showed high values with no difference $(\mathrm{p}>0.05)$ between control and stress treatments (Table 2). However, under high VPD and light incidence $(14: 00 \mathrm{~h})$, a sharp drop $(p<0.05)$ occurred in stressed plants compared to well hydrated plants, associated with similar gas exchange behavior (Figure 2). These results are in disagreement with those obtained in the field; under field conditions, jackfruit did not show a strong decrease at midday, in winter or in summer (CAO et al., 2006), suggesting tolerance to different environments.

Under stress, the minimal fluorescence yield $\left(F_{o}\right)$ in dark-adapted leaf tissue was reduced $(\mathrm{p}<0.05)$ compared to control plants on day 8 of water withholding, for both time periods and both species (Table 2). The $F_{v} / F_{m}$ value reflects the potential quantum efficiency of PSII and it is used as a sensitive indicator of plant photosynthetic performance (MAXWELL; JOHNSON, 2000). The decrease in this value coupled with $F_{o}$ increase in either control or water stress plants (Table 2) at 14:00 h suggests the occurrence of photoinhibitory damage in response to environmental stress (MAXWELL; JOHNSON, 2000; RIBEIRO et al., 2003). 


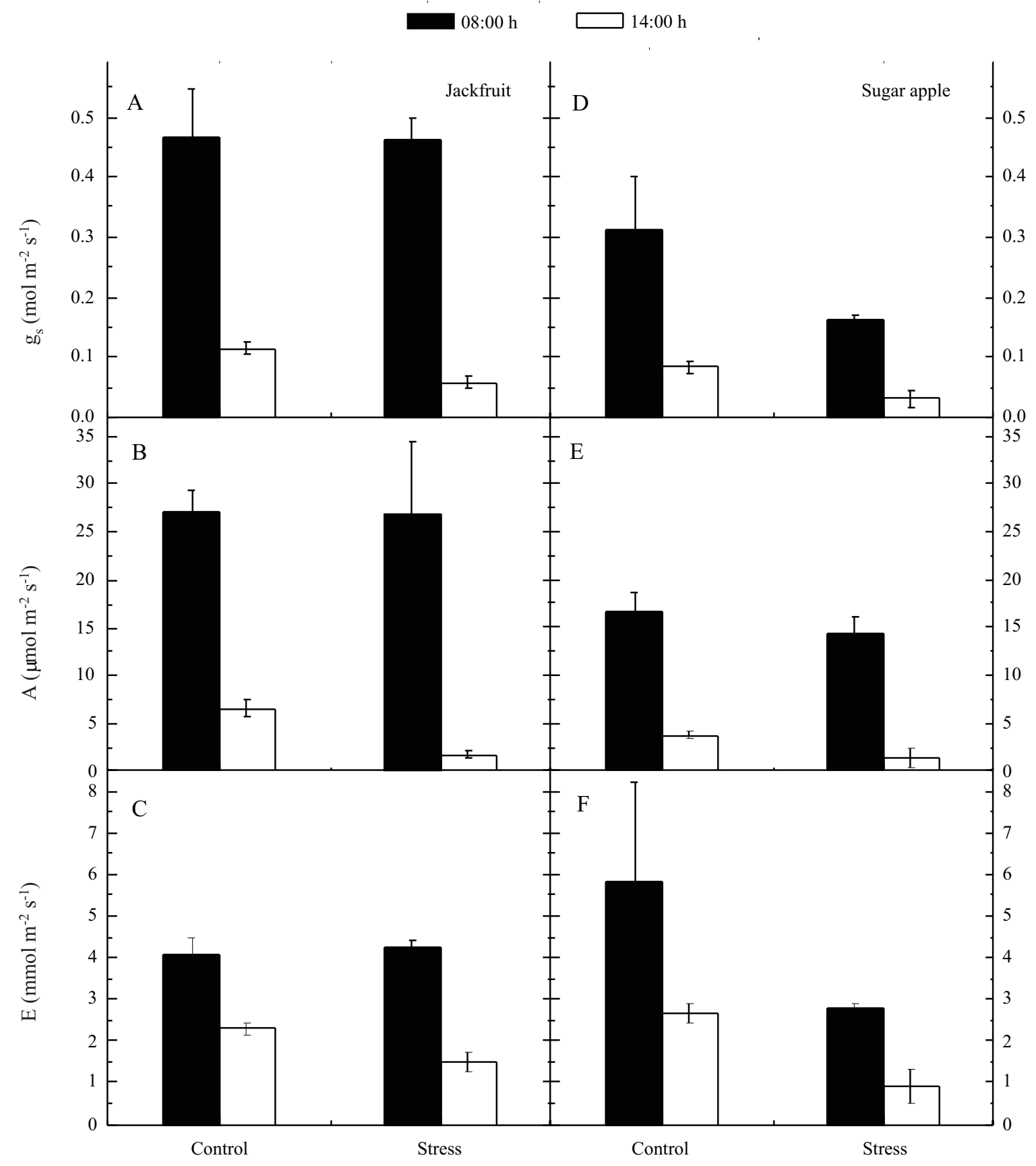

Treatments

Figure 2 - Gas exchange responses of young plants of two species fruit, jackfruit (A, B, C) and sugar apple (D, E, F) under water deficit period of eight days. Grown in pots under greenhouse conditions, in Recife 2007. Measurements at 08:00 and 14:00 h (low and high VPD, respectively), in well hydrated (control) and stressed plants (stress). Stomatal conductance $\left(g_{s}\right) ; \mathrm{CO}_{2}$ assimilation rate $(A)$ and transpiration rate $(E)$. Values are means $\pm \mathrm{SE}(\mathrm{n}=4)$

The reason the Chla/Chlb ratio showed no change under stress in jackfruit and sugar apple plants (data not shown), is probably due to the short duration of the stress event. However, under field conditions, jackfruit showed changes in the carotenoid to chlorophyll ratio from high in the winter to low in the summer, which is an interesting 
Table 2 - Water deficit effects on the potential quantum efficiency of PSII $\left(F_{v} / F_{m}\right)$, maximum $\left(F_{m}\right)$ and basal $\left(F_{o}\right)$ fluorescence yield, and relation between variable and basal fluorescence yield $\left(F_{v} / F_{o}\right)$ of young plants of two species fruit measurement at 06:00 and 14:00 $\mathrm{h}$ in well hydrated (control) and drought (stress) plants ${ }^{(1)}$. Grown in pots under greenhouse conditions, in Recife 2007

\begin{tabular}{|c|c|c|c|c|c|c|c|}
\hline \multirow{2}{*}{ Time (h) } & \multirow{2}{*}{ Treatment } & \multicolumn{3}{|c|}{ Jackfruit } & \multicolumn{3}{|c|}{ Sugar apple } \\
\hline & & $F_{o}$ & $F_{v} / F_{m}$ & $F_{v} / F_{o}$ & $F_{o}$ & $F_{v} / F_{m}$ & $F_{v} / F_{o}$ \\
\hline \multirow{2}{*}{ 06:00 } & Control & $451 \mathrm{~A}$ & $0.73 \mathrm{~B}$ & $2.77 \mathrm{~B}$ & $438 \mathrm{~B}$ & $0.79 \mathrm{~A}$ & $3.85 \mathrm{~A}$ \\
\hline & Stress & $408 \mathrm{~B}$ & $0.75 \mathrm{~B}$ & $3.05 \mathrm{~B}$ & $376 \mathrm{C}$ & $0.75 \mathrm{AB}$ & $3.10 \mathrm{~B}$ \\
\hline \multirow{2}{*}{ 14:00 } & Control & $499 \mathrm{~A}$ & $0.50 \mathrm{~A}$ & $0.84 \mathrm{~A}$ & $517 \mathrm{~A}$ & $0.56 \mathrm{~A}$ & $1.10 \mathrm{~A}$ \\
\hline & Stress & $274 \mathrm{~B}$ & $0.18 \mathrm{C}$ & $0.22 \mathrm{~B}$ & $314 \mathrm{~B}$ & $0.30 \mathrm{~B}$ & $0.46 \mathrm{~B}$ \\
\hline
\end{tabular}

${ }^{(1)}$ Data represent the mean of three replications; different letters in each time show significant difference by Student-Newman-Keuls test $(p<0.05)$. CV $8.96 \%$ and between time CV $10.06 \%$

behavior, since lower chlorophyll concentrations can reduce light absorption, thus alleviating the stress (CAO et al., 2006).

The organic solutes content was altered by water deficit (Table 3$)$, presenting increased $(p<0.05)$ leaf soluble sugar, protein and free amino acid contents in both species. The percentage increase was similar between these species for soluble sugar and protein contents, around $10 \%$ and $44 \%$, respectively. However, for free leaf amino acid content, the increase was $61 \%$ and $66 \%$ for jackfruit and sugar apple, respectively. Changes in soluble sugars were also determined in apple plant shoots under environmental stress (SIRCELJ et al., 2007; SIVACI, 2006). These findings appear to provide evidence of the adaptation processes plants have developed against unfavorable environmental conditions, suggesting that increased carbohydrate content could be a major adaptation process.

Certain biochemical parameters may be more consistent drought stress markers than the commonly used physiological parameters $g, A$ and $E$ for some species (SIRCELJ et al., 2007). Leaf free amino acid content increased, probably due to a reduction in growth and protein synthesis (SANTOS; PIMENTEL, 2009), to which both processes are considered to be very sensitive, as confirmed by several authors in the past (HANSON; HITZ, 1982; HSIAO, 1973). Nevertheless, amino acids and proteins continued to be synthesized in both species (Table 3), showing tolerance to water deficit and use of soluble sugars. The high leaf organic solutes content at 14:00 $\mathrm{h}$ verified in stressed plants is probably due to the high $\mathrm{CO}_{2}$ assimilation rate in the morning with low VPD (Figure 3). These results are in agreement with Santos and Pimentel (2009), who showed a strong relation between carbohydrate and free amino acids under water deficit in bean plants. When plants are exposed to environment stress their metabolism changes, showing plasticity under these conditions, a factor that could help during recovery, after a stress event.

Analysis of the results suggested that these species have a high tolerance to the stressful climatic conditions that occur in the semiarid region of northeastern Brazil. Moreover, jackfruit proved to be more tolerant than sugar apple due to the maintenance of higher leaf water potential under water deficit. However, further studies of these species under semiarid field conditions are necessary.

Table 3 - Changes in leaf soluble sugars, proteins and free amino acids contents of young plants of two species fruit submitted to eight days of drought (stress) and well hydrated plants (control). Grown in pots under greenhouse conditions, in Recife $2007^{(1)}$

\begin{tabular}{crrrrr}
\hline \multirow{2}{*}{ Variable $\left(\mu \mathrm{mol} \mathrm{g}^{-1} \mathrm{FW}\right)$} & \multicolumn{2}{c}{ Jackfruit } & & \multicolumn{2}{c}{ Sugar apple } \\
\cline { 2 - 3 } \cline { 5 - 6 } \cline { 5 - 6 } & Control & \multicolumn{1}{c}{ Stress } & & Control & \multicolumn{1}{c}{ Stress } \\
\hline Soluble sugars & $139.67 \mathrm{C}$ & $154.55 \mathrm{C}$ & & $215.20 \mathrm{~B}$ & $234.40 \mathrm{~A}$ \\
Protein & $6.61 \mathrm{~B}$ & $9.95 \mathrm{~A}$ & & $3.82 \mathrm{C}$ & $5.79 \mathrm{~B}$ \\
Amino acids & $9.96 \mathrm{C}$ & $26.42 \mathrm{~A}$ & & $4.80 \mathrm{D}$ & $14.15 \mathrm{~B}$ \\
\hline
\end{tabular}

(1)Data represent the mean of three replications; different letters in line show significant difference by Student-Newman-Keuls test $(p<0.05)$. CV $8.87 \%$ soluble sugars; $20.60 \%$ protein and $28.13 \%$ amino acids 


\section{Conclusions}

1. Well hydrated young plants of sugar apple have different stomatal behavior during the day when compared with young plants of jackfruit.

2. Jackfruit shown to be more tolerant to drought than sugar apple.

\section{Acknowledgements}

B. M. Rodrigues, B. D. Souza and R. J. C. M. Nogueira are grateful to the Conselho Nacional de Desenvolvimento Científico e Tecnológico (CNPq) for the fellowships granted.

\section{References}

ALBUQUERQUE, H. C. Situação atual e perspectivas para as anonáceas no Estado de Alagoas. In: SÃO JOSE, Abel Rebouças et al. Anonáceas, Produção e Mercado (Pinha, Graviola, Atemóia e Cherimólia). Vitória da Conquista: UESB/DFZ, 1997. p. 150-155.

BRADFORD, M. M. A rapid and sensitive method for the quantitation of microgram quantities of protein utilizing the principle of protein-dye binding. Analytical Biochemistry, v. 72, n. 01, p. 248-254, 1976.

CAO, K. F.; GUO, Y. H.; CAI, Z. Q. Photosynthesis and antioxidant enzyme activity in breadfruit, jackfruit and mangosteen in southern Yunnan, China. Journal Horticulturae Science Biotechnology, v. 81, n. 01, p. 168-172, 2006.

CHAVES, M. M.; MAROCO, J. P.; PEREIRA, J. S. Understanding plant responses to drought - from genes to the whole plant. Functional Plant Biology, v. 30, n. 02, p. 239-264, 2003.

DAMATTA, F. M. Ecophysiology of tropical tree crops: an introduction. Brazilian Journal of Plant Physiology, v. 19, n. 04, p. 239-244, 2007.

DUBOIS M. et al. Colorimetric method for determination of sugars and related substances. Analysis Chemical, v. 29, n. 02, p. $350-356,1956$.

ENDRES, L. Daily and seasonal variation of water relationship in sugar apple (Annona squamosa L.) under different irrigation regimes at semi-arid Brazil. Scientia Horticulturae, v. 113, n. 02, p. 149-154, 2007.

HANSON, H. D.; HITZ, W. D. Metabolic responses of mesophytes to plant water deficits. Annual Review of Plant Physiology, v. 33, n. 01, p. 163-203, 1982.

HSIAO, T. C. Plant response to water stress. Annual Review of Plant Physiology, v. 24, n. 01, p. 519-570, 1973.
KRAMER, P. J.; BOYER, J. S. Water relations of plants and Soils. San Diego: Academic Press, 1995. 495 p.

LAWLOR, D. W. Limitation to photosynthesis in water-stressed leaves: stomata vs. metabolism and the role of ATP. Annals of Botany, v. 89, n. 07, p. 871-885, 2002.

LICHTENTHALER, H. K.; WELLBURN, A. R. Determination of total carotenoids and chlorophylls a and $\mathrm{b}$ of leaf extracts in different solvents. Biochemical Society Transactions, v. 11, n. 03, p. 591-592, 1983.

MAXWELL, K.; JOHNSON, G. N. Chlorophyll fluorescence - a practical guide. Journal of Experimental Botany, v. 51, n. 345, p. 659-668, 2000.

MIRANDA, M. R. A. et al. Caracterização físico química e histológica do desenvolvimento de sapoti. Revista Ciência Agronômica, v. 39, n. 04, p. 575-582, 2008.

OKUMURA, H. H. et al. Fertilizantes minerais e orgânicos na formação de mudas enxertadas de gravioleira. Revista Ciência Agronômica, v. 39, n. 04, p. 590-596, 2008.

RIBEIRO, R. V. et al. High temperature effects on the response of photosynthesis to light in sweet Orange plants infected with Xylella fastidiosa. Brazilian Journal of Plant Physiology, v. 15, n. 02, p. 89-97, 2003.

ROLLAND, F.; BAENA-GONZALES, E.; SHEEN, J. Sugar sensing and signaling in plants: conserved and novel mechanisms. Annual Review of Plant Biology, v. 57, n. 01, p. 675-709, 2006.

SANTOS, M. G. et al. The role of inorganic phosphate on photosynthesis recovery of common bean after a mild water deficit. Plant Science, v. 170, n. 03, p. 659-664, 2006.

SANTOS, M. G.; PIMENTEL, C. Daily balance of leaf sugars and amino acids as indicators of common bean (Phaseolus vulgaris L.) metabolic response and drought intensity. Physiology Molecular Biology of Plants, v. 15, n. 01, p. 23-30, 2009.

SCHULTZ, H. R. Differences in hydraulic architecture account for near-isohydric and anisohydric behaviour of two fieldgrown Vitis vinifera L. cultivars during drought. Plant and Cell Environment, v. 26, n. 08, p. 1393-1405, 2003.

SINCLAIR, T. R.; ZWIENIECKI, M. A.; HOLBROOK, N. M. Low leaf hydraulic conductance associated with drought tolerance in soybean. Physiologia Plantarum, v. 132, n. 03, p. 446-451, 2008.

SIRCELJ, H. et al. Detecting different levels of drought stress in apple trees (Malus domestica Borkh.) with selected biochemical and physiological parameters. Scientia Horticulturae, v. 113, n. 04, p. 362-369, 2007.

SIVACI, A. Seasonal changes of total carbohydrate contents in three varieties of apple (Malus sylvestris Miller) stem cuttings. Scientia Horticulturae, v. 109, n. 03, p. 234-327, 2006.

TARDIEU, F.; SIMONNEAU, T. Variability among species of stomatal control under fluctuating soil water status and 
evaporative demand: modelling isohydric and anisohydric behaviours. Journal of Experimental Botany, v. 49, n. 320, p. 419-432, 1998.

VAN KOOTEN, O.; SNEL, J. F. H. The use of chlorophyll fluorescence nomeclature in plant stress physiology. Photosynthesis Research, v. 25, n. 02, p. 147-150, 1990.
WINGLER, A. et al. The role of sugars in integrating environmental signals during the regulation of leaf senescence. Journal of Experimental Botany, v. 57, n. 02, p. 391-399, 2006.

YEMM, E. W.; COOCKING, E. C. The determination of amino acids with ninhydrin. Analyst, v. 80, n. 02, p. 209-213, 1955. 